\title{
Effect of sowing technology on the yield and harvest grain moisture content of maize (Zea mays L.) hybrids with different genotypes
}

\author{
Eszter Murányi \\ University of Debrecen Faculty of Agricultural and Food Sciences and Environmental Management \\ Institute of Crop Science, Debrecen \\ emuranyi@agr.unideb.hu
}

\section{SUMMARY}

From the aspect of the efficiency of maize production harvest grain moisture content shall be considered beside the amount of harvested grain yield. Hybrids with different genotypes and vegetation period length lose their moisture content different that is affected by row spacing and plant density - among agrotechnical production factors - depending on the given crop year. In the present research work three crop years with different weather conditions were studied (2013, 2014, and 2015). The small-plot field experiment was set up at the Látókép Field Research Centre of the University of Debrecen, Centre for Agricultural Sciences with four replications on a chernozem soil type. The effect of three factors was analysed in the experiment on yield amount and its moisture content. Factors were row spacing (45 and $76 \mathrm{~cm})$, plant density (50, 70 and 90 thousand plants $h^{-1}$ ), while hybrids were of very early (Sarolta: FAO 290), early (DKC 4014: FAO 320, P 9175: FAO 330, P 9494: FAO 390) and medium (SY Afinity: FAO 470) ripening.

In the crop year of 2013 the highest yield was produced - regarding the average of the hybrids - by the application of a row spacing of $45 \mathrm{~cm}(4.5 \%, 673 \mathrm{~kg} \mathrm{ha}$ ), however there was no significant difference between the yield of the populations of different row spacings. Significant difference $\left(14.9 \%, 1751 \mathrm{~kg} \mathrm{ha}^{-1} ; 6.3 \%, 583 \mathrm{~kg} \mathrm{ha}^{-1}\right)$ could be found in case of yield between different row spacing applications in 2014 and 2015. The effect of insufficiently distributed low amount of precipitation and lasting heat days in 2015 could be revealed in yield amounts and harvest grain yield moisture content results that were lower than in the previous years. In 2015 grain yield moisture content varied between 10.3 and $13.9 \%$ in case of a row spacing of $45 \mathrm{~cm}$, while by $76 \mathrm{~cm}$ between 11.0 and $13.9 \%$.

Keywords: maize, row spacing, plant density, yield, moisture at harvest

\section{ÖSSZEFOGLALÁS}

A kukoricatermesztés eredményessége szempontjából a betakaritott szemtermés nagysága mellett fontos a betakaritáskor mért szemnedvesség tartalom. Az eltérö genotípusú és tenyészidejü hibridek vízleadása különbözöen alakul, amelyre az agrotechnikai tényezők közül a sortávolság és a tőszám hatást gyakorol az évjárattól függően. A kutatásunk során 3 eltérö időjárási adottságú évet vizsgáltunk (2013, 2014, 2015). A szántóföldi kisparcellás kisérlet 4 ismétlésben a Debreceni Egyetem ATK Látóképi Kisérleti Telepén lett beállitva mészlepedékes csernozjom talajon. A kísérletben három tényezö hatását vizsgáltuk a termés és a betakaritáskor mért szemnedvesség alakulására. A tényezök a sortávolság (45 és $76 \mathrm{~cm}$ ), a növényállomány sürüség (50, 70 és 90 ezer növény/ha), a hibridek igen korai érésü (Sarolta: FAO 290), korai érésü (DKC 4014: FAO 320, P 9175: FAO 330, P 9494: FAO 390) és középérésüek (SY Afinity: FAO 470) voltak.

A 2013. tenyészévben a $45 \mathrm{~cm}$ sortávolságra beállitott állomány érte el a nagyobb termést a hibridek átlagában (4,5\%, 673 kg/ha), azonban a két sortávolság termése között nem volt jelentös eltérés. A 2014, 2015. évben a sortávolságok között szignifikáns különbség volt (14,9\%, $1751 \mathrm{~kg} / \mathrm{ha} ; 6,3 \%, 583 \mathrm{~kg} / \mathrm{ha}$ ). A 2015. évben a nem megfelelö eloszlású, kevés csapadéknak és a hosszabb ideig tartó höségnapok hatása megjelent a termésmennyiség alakulásában és a betakaritáskor mért szemnedvesség tartalomban, amelyek az elözö évekhez viszonyitva jóval kisebbek voltak. A 2015. évben a $45 \mathrm{~cm}$ sortávolságnál 10,3-13,9\%, a $76 \mathrm{~cm}$ sortávolságnál 11,0-13,9\% között változtak a szemnedvesség értékek.

Kulcsszavak: kukorica, sortávolság, növényszám, termés, szemnedvesség-tartalom

\section{INTRODUCTION}

The study of the applicability of narrow row spacing has lead to contrary results both in Hungary and abroad: decreasing row spacing resulted yield increment according to the research results of Lutz et al. (1971), Nagy (1983), Porter et al. (1997), Widdicombe and Thelen (2002), Shapiro and Wortmann (2006), while according to the results of Giesbrecht (1969), Johnson et al. (1998), Farnham (2001), Ma et al. (2003) the application of even narrow row spacing did not result any yield increment.

According to Porter et al. (1997) the chosen hybrid and weather conditions of the given vegetation period have the most expressed effect on the harvest grain moisture content. Widdicombe and Thelen (2002) set up their research experiment with row distances of 76,
56 and $38 \mathrm{~cm}$ and 5 different plant density settings between 56 and 90 thousand plants ha ${ }^{-1}$. Parallel to the decreasing row spacing yield increased by $2-4 \%$ and harvest grain moisture content decreased, while it increased only slightly parallel to the increasing plant density. Highest yield amount was measured by the application of the plant density of 90000 plants ha-1. Shapiro and Wortmann (2006) realized 4\% yield increment parallel to the decreasing row spacing.

In the experiment of Giesbrecht (1969) row spacing had no effect on yield amount, while the yield of hybrids significantly increased due to the increasing plant density. According to the results of Farnham (2001) maize populations with a row spacing of $76 \mathrm{~cm}$ produced higher yield than that of $38 \mathrm{~cm}$ regarding the average of the studied crop years, production sites and plant 
densities. Harvest grain moisture content was significantly lower in case of the row spacing of $38 \mathrm{~cm}$, than in case of $76 \mathrm{~cm}$.

\section{MATERIAL AND METHODS}

The small plot field experiment was set up with 4 replications at the Látókép Field Research Centre of the University of Debrecen, Centre for Agricultural Sciences with a split-split-plot design. The experimental soil was a calcareous chernozem. Five maize hybrids with different genotypes were involved into the experiment that were Sarolta (FAO 290), DKC 4014 (FAO 320), P 9175 (FAO 330), P 9494 (FAO 390) and SY Afinity (FAO 470). In the present research work the effect of row spacing (45 and $76 \mathrm{~cm}$ ) and plant density $(50,70$, 90 thousand plants ha ${ }^{-1}$ ) on yield amount and its harvest moisture content was analysed.

Harvest was executed by a Sampo small-plot combine harvester. Harvest dates were the $30^{\text {th }}$ September in 2013 , the $20^{\text {th }}$ October in 2014 and the $20^{\text {th }}$ September in 2015. Grain moisture content and harvested grain yield amount were measured at harvest and grain yield amount with moisture content of $14 \%$ was calculated using these data. For the determination of the harvest grain moisture content grain yield samples were dried in a laboratory oven until constant weight and both wet and dry yields were measured, thus moisture content (\%) was calculated according to a formula.

Weather conditions of the studied crop years were different. Table 1 shows the precipitation amount before and during the vegetation, just as the average temperature data. The amount of precipitation before the vegetation period was higher in the crop years of 2012 and 2013 than the long-term average. This is resulted by the high amount of precipitation in March $(136.3 \mathrm{~mm})$ that filled the water stock of the chernozem soil. Regarding the vegetation, an amount of precipitation less than the long-term average fell in June and July. In the crop year of 2013-2014 the amount of precipitation before vegetation was low $(167.1 \mathrm{~mm})$ while in June which can be considered as a critical month from the aspect of maize development - only $7.9 \mathrm{~mm}$ precipitation fell (that was $71.6 \mathrm{~mm}$ less than the long-term average value). Regarding the whole vegetation period it can be stated that the distribution of precipitation was unfavourable. In the crop year of 2014-2015 the lack of precipitation and its unfavourable distribution were associated with high temperature values.
Registered temperature values were higher than the long-term average values in every crop year. Temperature values of the vegetation period of 2015 showed extreme deviances from the 30-years average values.

Statistical evaluation of result data was executed by three-way ANOVA and Pearson correlation analysis using the software SPSS 13.0 for Windows. The analysed three factors were row spacing (A), plant density (B) and hybrid (C). According to Sváb (1981) the strength of relationships was defined as follows: if r-value was $<0.4$ weak, if it was between 0.4 and 0.7 medium and in case of an r-value of $>0.9$ strong correlations were determined.

\section{RESULTS AND DISCUSSION}

The effect of the application of different row spacings and plant densities on grain yield and grain harvest moisture content of five maize hybrids with different genotypes and vegetation period lengths were studied in the crop years 2013, 2014 and 2015.

In the crop year of 2013 the highest yield was produced - regarding the average of the hybrids - by the application of a row spacing of $45 \mathrm{~cm}\left(4.5 \%, 673 \mathrm{~kg} \mathrm{ha}^{-1}\right)$, however there was no significant difference between the yield of the populations of different row spacings (Table 2).

Among the studied hybrids SY Afinity showed yield decrease parallel to the decreasing row spacing. The highest yield increment was observed in case of the hybrid P 9494. The highest yield amount was produced in case of the densest population (90 $\left.000 \mathrm{ha}^{-1}\right)$ with a row spacing of $45 \mathrm{~cm}$, increasing plant density resulted yield increment in case of all hybrids. Yield amounts varied between 10.8 and $17.7 \mathrm{tha}^{-1}$ in case of a row spacing of $45 \mathrm{~cm}$ depending on the plant density and hybrid, while in case of a row spacing of $76 \mathrm{~cm}$ it ranged between 11.8 and $15.9 \mathrm{t} \mathrm{ha}^{-1}$. Highest yield amounts were measured in case of all plant densities in case of the hybrid P 9494. In case of a row spacing of $76 \mathrm{~cm}$ the highest yield was realized by the plant density of 70000 plants $\mathrm{ha}^{-1}$. Significant differences were found between the yields in case of different hybrids and plant densities. Significant difference was determined between the yield amount of the plant densities 50000 and 70000 plants ha $^{-1}$, just as between 50000 and 90000 plants ha-1.

Amount of precipitation $(\mathrm{mm})$ and temperature $\left({ }^{\circ} \mathrm{C}\right)$ data before and during maize vegetation

\begin{tabular}{|c|c|c|c|c|}
\hline Year & $2012-2013$ & 2013-2014 & 2014-2015 & 30-years average (1961-1990) \\
\hline \multicolumn{5}{|c|}{ Precipitation (mm) } \\
\hline Before maize vegetation (October-March) & 332.7 & 167.1 & 215.6 & 220.2 \\
\hline During maize vegetation (April-September) & 242.9 & 385.4 & 303.8 & 345.1 \\
\hline Total & 575.6 & 552.5 & 519.4 & 565.3 \\
\hline \multicolumn{5}{|c|}{ Monthly average temperature $\left({ }^{\circ} \mathrm{C}\right)$} \\
\hline Before maize vegetation (October-March) & 3.6 & 6.4 & 4.8 & 2.9 \\
\hline During maize vegetation (April-September) & 17.5 & 17.4 & 18.3 & 16.8 \\
\hline Average & 10.5 & 11.9 & 11.5 & 9.8 \\
\hline
\end{tabular}


Yield of the studied hybrids in case of different row spacings and plant densities $\left(\mathrm{t} \mathrm{ha}^{-1}\right)$

(Debrecen - Látókép 2013-2015)

\begin{tabular}{|c|c|c|c|c|c|c|c|c|c|}
\hline \multirow{2}{*}{\multicolumn{2}{|c|}{$\begin{array}{c}\mathrm{H}^{*} \\
\text { Plant density }\end{array}$}} & \multicolumn{4}{|c|}{ Row spacing $45 \mathrm{~cm}$} & \multicolumn{4}{|c|}{ Row spacing $76 \mathrm{~cm}$} \\
\hline & & 50 & 70 & 90 & $\mathrm{x}$ & 50 & 70 & 90 & $\mathrm{x}$ \\
\hline \multirow{5}{*}{$\begin{array}{l}\text { The } 2013 \\
\text { growing } \\
\text { season }\end{array}$} & $\mathrm{H} 1$ & 10.8 & 12.6 & 12.9 & 12.1 & 11.9 & 12.0 & 11.8 & 11.9 \\
\hline & $\mathrm{H} 2$ & 13.0 & 13.2 & 14.8 & 13.7 & 12.2 & 13.8 & 12.8 & 12.9 \\
\hline & $\mathrm{H} 3$ & 14.1 & 16.8 & 17.6 & 16.2 & 15.9 & 15.9 & 15.2 & 15.7 \\
\hline & $\mathrm{H} 4$ & 16.7 & 17.5 & 17.7 & 17.3 & 15.1 & 15.6 & 14.3 & 15.0 \\
\hline & $\mathrm{H} 5$ & 13.6 & 14.6 & 16.9 & 15.0 & 14.7 & 15.4 & 15.9 & 15.3 \\
\hline \multicolumn{2}{|c|}{$\mathrm{x}$} & 13.6 & 14.9 & 16.0 & 14.8 & 14.0 & 14.5 & 14.0 & 14.2 \\
\hline \multicolumn{10}{|c|}{$\mathrm{LSD}_{5 \%} \mathrm{~A}: 0.9, \mathrm{LSD}_{5 \%} \mathrm{~B}: 0.3, \mathrm{LSD}_{5 \%} \mathrm{C}: 0.5, \mathrm{LSD}_{5 \%} \mathrm{~A} * \mathrm{~B}: 0.4, \mathrm{LSD}_{5 \%} \mathrm{~A} * \mathrm{~B} * \mathrm{C}: 1.3$} \\
\hline \multirow{5}{*}{$\begin{array}{l}\text { The } 2014 \\
\text { growing } \\
\text { season }\end{array}$} & $\mathrm{H} 1$ & 10.3 & 10.1 & 9.6 & 10.0 & 9.6 & 11.0 & 12.1 & 10.9 \\
\hline & $\mathrm{H} 2$ & 12.5 & 11.5 & 10.9 & 11.6 & 12.3 & 13.6 & 14.7 & 13.6 \\
\hline & $\mathrm{H} 3$ & 13.2 & 13.3 & 13.3 & 13.3 & 13.1 & 14.2 & 15.5 & 14.3 \\
\hline & $\mathrm{H} 4$ & 12.4 & 12.5 & 12.1 & 12.3 & 14.3 & 15.0 & 14.0 & 14.4 \\
\hline & H5 & 12.5 & 13.3 & 9.3 & 11.7 & 13.2 & 15.1 & 15.3 & 14.5 \\
\hline \multicolumn{2}{|c|}{$\mathrm{x}$} & 12.2 & 12.1 & 11,0 & 11.8 & 12.5 & 13.8 & 14.3 & 13.5 \\
\hline \multicolumn{10}{|c|}{$\mathrm{LSD}_{5 \%} \mathrm{~A}: 0.9, \mathrm{LSD}_{5 \%} \mathrm{~B}: 0.5, \mathrm{LSD}_{5 \%} \mathrm{C}: 0.5, \mathrm{LSD}_{5 \%} \mathrm{~A} * \mathrm{~B}: 0.7, \mathrm{LSD}_{5 \%} \mathrm{~A} * \mathrm{~B} * \mathrm{C}: 1.2$} \\
\hline \multirow{5}{*}{$\begin{array}{l}\text { The } 2015 \\
\text { growing } \\
\text { season }\end{array}$} & H1 & 6.9 & 7.7 & 8.2 & 7.6 & 7.9 & 8.0 & 7.3 & 7.7 \\
\hline & $\mathrm{H} 2$ & 8.8 & 8.7 & 9.4 & 9.0 & 9.8 & 10.5 & 9.8 & 10.0 \\
\hline & H3 & 10.2 & 10.9 & 9.9 & 10.3 & 10.7 & 11.3 & 10.3 & 10.7 \\
\hline & $\mathrm{H} 4$ & 10.1 & 10.6 & 9.4 & 10.0 & 10.8 & 11.6 & 10.2 & 10.9 \\
\hline & H5 & 9.1 & 9.7 & 9.8 & 9.5 & 10.3 & 9.9 & 9.8 & 10.0 \\
\hline \multicolumn{2}{|c|}{$\mathrm{x}$} & 9.0 & 9.5 & 9.3 & 9.3 & 9.9 & 10.2 & 9.5 & 9.9 \\
\hline
\end{tabular}

Note: * - H1: Sarolta; H2: DKC 4014; H3: P 9175; H4: P 9494; H5: SY Afinity

In the crop year of 2014 the highest yield was measured in case of the population with row spacing of $76 \mathrm{~cm}$ : its yield was $14.9 \%$, that was $1,751 \mathrm{~kg} \mathrm{ha}^{-1}$ higher than that of a row spacing of $45 \mathrm{~cm}$. Significant difference was found between yield of populations of the two row spacings. All hybrids showed yield decrease parallel to decreasing row spacings. In case of a row spacing of $45 \mathrm{~cm}$ the yield amount was similar by the plant densities 50000 and 70000 plants $^{-1}$, while the lowest yield amount was measured in case of the plant density of 90000 plants ha $^{-1}$. In case of the row spacing of $76 \mathrm{~cm}$ yield amounts increased parallel to the increasing plant density; yield amounts showed maximal values by 90000 plants ha ${ }^{-1}$ regarding the average of the hybrids. Despite the increasing plant density the hybrids P 9175 and P 9494 produced balanced yield amounts by the application of a row spacing of $45 \mathrm{~cm}$, i.e. they showed favourable reaction towards increasing plant density. Due to the intense increasing plant density the hybrid SY Afinity produced minimal yield amount by the highest plant density. Depending on the studied factors yield amount varied between 9.3 and $13.3 \mathrm{t} \mathrm{ha}^{-1}$ by a row spacing of $45 \mathrm{~cm}$, while in case of that of $76 \mathrm{~cm}$ it ranged between 9.6 and $15.5 \mathrm{t} \mathrm{ha}^{-1}$. Yield amounts were affected by all studied factors, just as the interaction of the studied factors was significant.

In the crop year of 2015 hybrids produced maximal yields by the application of a plant density of 70000 plants ha ${ }^{-1}$ in case of both row spacings. The yield of the population - regarding the average of the hybrids with a row spacing of $76 \mathrm{~cm}$ was $6.3 \%\left(583 \mathrm{~kg} \mathrm{ha}^{-1}\right)$ higher than that of the populations with row spacing of
$45 \mathrm{~cm}$, which was evaluated as significant difference. Decreasing row spacing resulted in yield decrement in case of all hybrids. The lowest yield was measured in case of all plant densities and the row spacing of $45 \mathrm{~cm}$ by the hybrid Sarolta, while in case of the row spacing of $76 \mathrm{~cm}$ its yield was rather balanced. The highest yields were produced by the hybrids P 9175 and P 9494. Yield amounts varied between 6.9 and $10.9 \mathrm{t} \mathrm{ha}^{-1}$ by the application of the row spacing of $45 \mathrm{~cm}$, while in case of that of $76 \mathrm{~cm}$ it ranged between 7.3 and $11.6 \mathrm{t} \mathrm{ha}^{-1}$. Significant difference was determined between the yield amount of the plant densities 50000 and 70000 plants ha ${ }^{-1}$, just as between 50000 and 90000 plants ha ${ }^{-1}$.

Despite the sufficient amount of precipitation in the crop year of 2014 the yield of the population with $45 \mathrm{~cm}$ did not reach the level of the population with $76 \mathrm{~cm}$ row spacing. In contrast in the crop year of 2013 despite the lower amount of precipitation and as an effect of the high amount of precipitation in March that filled the soil water stock the application of different row spacings resulted balanced yields. The effect of unfavourably distributed and low amount of precipitation, just as heat days that lasted longer in the crop year of 2015 could be revealed in the yield amount that was significantly lower than in the previous crop years.

Harvest grain yield moisture content was mainly affected by the genotype of the given hybrid, just as the weather conditions during the ripening phase and before harvest. Row spacings and plant densities applied in the experiment were influencing factors as well.

Grain yield moisture content showed different development in the studied crop years (Table 3). 
AgrÁRTUdOMÁNYi KÖZLEMÉNYEK, 2016/68.

Harvest grain yield moisture content of the studied hybrids depending on the row spacing and plant density (Debrecen - Látókép 2013-2015)

\begin{tabular}{|c|c|c|c|c|c|c|c|c|c|}
\hline \multirow{2}{*}{\multicolumn{2}{|c|}{$\begin{array}{c}\mathrm{H}^{*} \\
\text { Plant density }\end{array}$}} & \multicolumn{4}{|c|}{ Row spacing $45 \mathrm{~cm}$} & \multicolumn{4}{|c|}{ Row spacing $76 \mathrm{~cm}$} \\
\hline & & 50 & 70 & 90 & $\mathrm{x}$ & 50 & 70 & 90 & $\mathrm{x}$ \\
\hline \multirow{5}{*}{$\begin{array}{c}\text { The } 2013 \\
\text { growing } \\
\text { season }\end{array}$} & H1 & 15.3 & 15.2 & 15.7 & 15.4 & 15.1 & 14.5 & 14.9 & 14.8 \\
\hline & $\mathrm{H} 2$ & 16.7 & 15.8 & 16.1 & 16.2 & 16.2 & 16.1 & 15.9 & 16.1 \\
\hline & $\mathrm{H} 3$ & 17.5 & 16.2 & 16.4 & 16.7 & 15.7 & 14.9 & 15.9 & 15.5 \\
\hline & $\mathrm{H} 4$ & 17.4 & 16.5 & 16.2 & 16.7 & 15.4 & 15.2 & 15.7 & 15.4 \\
\hline & H5 & 22.9 & 22.7 & 21.2 & 22.3 & 22.6 & 21.5 & 22.4 & 22.2 \\
\hline \multicolumn{2}{|c|}{$\mathrm{x}$} & 18.0 & 17.3 & 17.1 & 17.4 & 17.0 & 16.4 & 17.0 & 16.8 \\
\hline \multicolumn{10}{|c|}{ LSD $_{5 \%}$ A: 0.1, LSD $5 \%$ B: 0.3, LSD ${ }_{5 \%}$ C: 0.6, LSD $_{5 \%} A * B: 0.5$, LSD $_{5 \%}$ A*B*C: 1.4} \\
\hline \multirow{5}{*}{$\begin{array}{l}\text { The } 2014 \\
\text { growing } \\
\text { season }\end{array}$} & H1 & 14.9 & 15.0 & 14.7 & 14.9 & 15.5 & 15.2 & 15.3 & 15.3 \\
\hline & $\mathrm{H} 2$ & 14.6 & 14.5 & 14.4 & 14.5 & 15.6 & 15.7 & 15.4 & 15.6 \\
\hline & $\mathrm{H} 3$ & 16.0 & 15.6 & 15.4 & 15.6 & 15.7 & 15.7 & 16.1 & 15.8 \\
\hline & $\mathrm{H} 4$ & 16.1 & 15.6 & 15.1 & 15.6 & 16.6 & 16.6 & 18.1 & 17.1 \\
\hline & $\mathrm{H} 5$ & 17.8 & 16.4 & 15.7 & 16.6 & 18.5 & 18.2 & 18.4 & 18.4 \\
\hline \multicolumn{2}{|c|}{$\begin{array}{c}\mathrm{x} \\
\end{array}$} & 15.9 & 15.4 & 15.0 & 15.4 & 16.4 & 16.3 & 16.7 & 16.4 \\
\hline \multicolumn{10}{|c|}{ 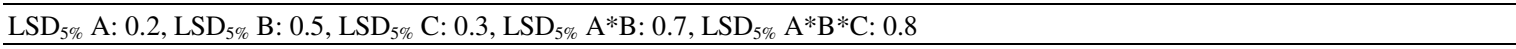 } \\
\hline \multirow{5}{*}{$\begin{array}{c}\text { The } 2015 \\
\text { growing } \\
\text { season }\end{array}$} & H1 & 10.3 & 11.2 & 11.3 & 10.9 & 11.6 & 11.2 & 11.0 & 11.3 \\
\hline & $\mathrm{H} 2$ & 11.1 & 11.4 & 11.7 & 11.4 & 11.6 & 11.4 & 11.4 & 11.5 \\
\hline & $\mathrm{H} 3$ & 12.8 & 11.8 & 11.7 & 12.1 & 13.0 & 12.5 & 12.1 & 12.5 \\
\hline & $\mathrm{H} 4$ & 12.3 & 12.4 & 12.3 & 12.3 & 13.2 & 12.1 & 11.6 & 12.3 \\
\hline & H5 & 13.2 & 13.9 & 13.4 & 13.5 & 13.9 & 13.0 & 12.3 & 13.1 \\
\hline \multicolumn{2}{|c|}{$\mathrm{x}$} & 11.9 & 12.1 & 12.1 & 12.1 & 12.7 & 12.0 & 11.7 & 12.1 \\
\hline
\end{tabular}

Note: * - H1: Sarolta; H2: DKC 4014; H3: P 9175; H4: P 9494; H5: SY Afinity

The highest grain yield moisture contents were measured in case of the row spacing of $45 \mathrm{~cm}$ in 2013 , and in case of the $76 \mathrm{~cm}$ in 2014, while regarding the average of the studied factors the values of the two row spacing variants were similar. The highest grain moisture content was measured by the hybrid SY Afinity in all crop years, while the lowest in case of the hybrid with the shortest vegetation period that was Sarolta.

Grain yield moisture content varied between 15.2 and $22.9 \%$ in case of the row spacing of $45 \mathrm{~cm}$ in 2013 while in case of that of $76 \mathrm{~cm}$ between 14.5 and $22.6 \%$. Row spacing, plant density and the applied hybrid resulted in significant differences in grain moisture content, while the interaction between the studied factors did not result any significant difference. By the application of $45 \mathrm{~cm}$ grain yield moisture content decreased parallel to increasing plant density, while in case of the row spacing of $76 \mathrm{~cm}$ the lowest values were measured in case of the plant density of 70000 plants ha ${ }^{-1}$. Significant difference could be revealed between grain yield moisture content of the populations with densities of 50 and 70000 plants ha ${ }^{-1}$. Yield moisture content of the populations with a row spacing of $45 \mathrm{~cm}$ was $3.6 \%$ higher than that of $76 \mathrm{~cm}$.

Due to the wet September and early October 2014 harvest date was delayed (20 ${ }^{\text {th }}$ October 2014). Depending on the applied plant density and hybrid extreme values of yield moisture content varied between 14.4 and 17.8\% in case of the row spacing of $45 \mathrm{~cm}$, while by $76 \mathrm{~cm}$ between 15.2 and $18.5 \%$. Row spacing and the applied hybrid resulted in significant differences in the development of grain yield moisture content. Yield moisture content was $6.4 \%$ higher in case of the row spacing of $76 \mathrm{~cm}$ regarding the average of the studied factors.
The lowest grain yield moisture content values were measured in the crop year of 2015. Grain yield moisture content varied between 10.3 and $13.9 \%$ in case of a row spacing of $45 \mathrm{~cm}$, while by $76 \mathrm{~cm}$ between 11.0 and $13.9 \%$. Significant difference was resulted by the application of hybrids with different genotypes.

Due to the increasing row spacing yield amount and its moisture content decreased in 2013. The correlation between the studied factors was weak (Table 4). In the crop year of 2014 yield amount and grain moisture content increased parallel to increasing row spacing; medium correlations $\left(0.519^{* *}, 0.411^{* *}\right)$ were found between corresponding factors. Weak correlation could be revealed between yield amount and grain moisture content $(0.282 *)$ in 2013 , while in 2014 and 2015 this correlation proved to be medium $\left(0.497^{* *}, 0.512^{* *}\right)$.

Table 4

Correlation between the analysed parameters (Debrecen - Látókép 2013, 2014, 2015)

\begin{tabular}{lccc}
\hline & Row spacing & Plant density & Yield \\
\hline & \multicolumn{3}{c}{2013} \\
\hline Yield & -0.118 & 0.245 & 1 \\
Grain moisture content & -0.119 & -0.068 & $0.282^{*}$ \\
\hline & & 2014 & \\
\hline Yield & $0.519^{* *}$ & 0.024 & 1 \\
Grain moisture content & $0.411^{* *}$ & -0.090 & $0.497 * *$ \\
\hline & & 2015 & \\
\hline Yield & 0.165 & 0.089 & 1 \\
Grain moisture content & 0.040 & 0.186 & $0.512^{* *}$ \\
\hline
\end{tabular}

Note: * - correlation is significant at the 0.05 level, $* *$ - correlation is significant at the 0.01 level 
According to Figure 1-3 it can be stated that hybrids can be classified into different categories regarding their produced yields and their moisture content. From the aspect of hybrid choice it is optimal if the given hybrid produces high yield amount with low harvest grain yield moisture content. These hybrids can be identified in the following Figures: in case of both studied row spacings the hybrids P 9175 and P 9494 produced high yield amount with low moisture content in 2013, while in 2014 it were P 9175 and DKC 4014 in case of a row spacing of $76 \mathrm{~cm}$ and in 2015 - in case of a row spacing of $76 \mathrm{~cm}$ as well - DKC 4014 . The hybrid Sarolta produced low yield amount with low moisture content in all crop years and in contrast SY Afinity produced high yield amounts with rather high moisture content.

Figure 1: Relationship between yield amount $\left(\mathrm{t} \mathrm{ha}^{-1}\right)$ and its moisture content (\%) by row spacings of 45 and $76 \mathrm{~cm}$ in the crop year of 2013 (Debrecen - Látókép 2013)

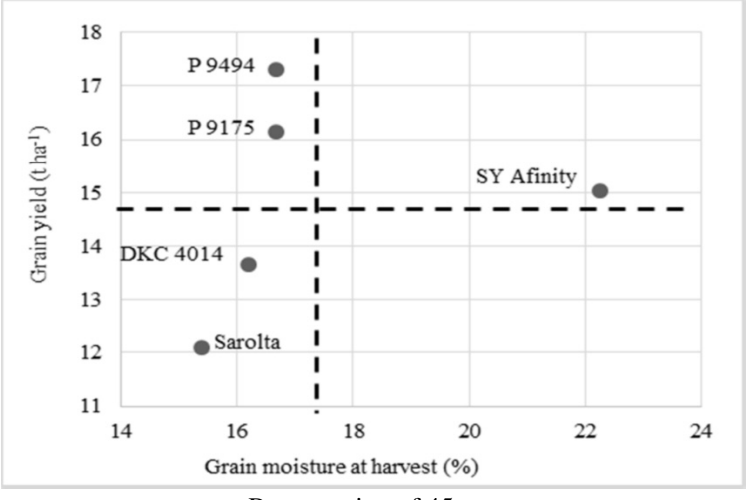

Row spacing of $45 \mathrm{~cm}$

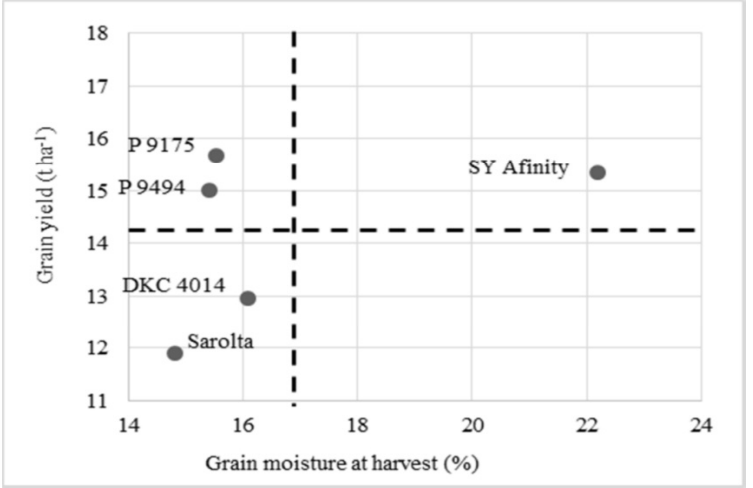

Row spacing of $76 \mathrm{~cm}$

Figure 2: Relationship between yield amount (t ha-1) and its moisture content (\%) by row spacings of 45 and $76 \mathrm{~cm}$ in the crop year of 2014 (Debrecen - Látókép 2014)
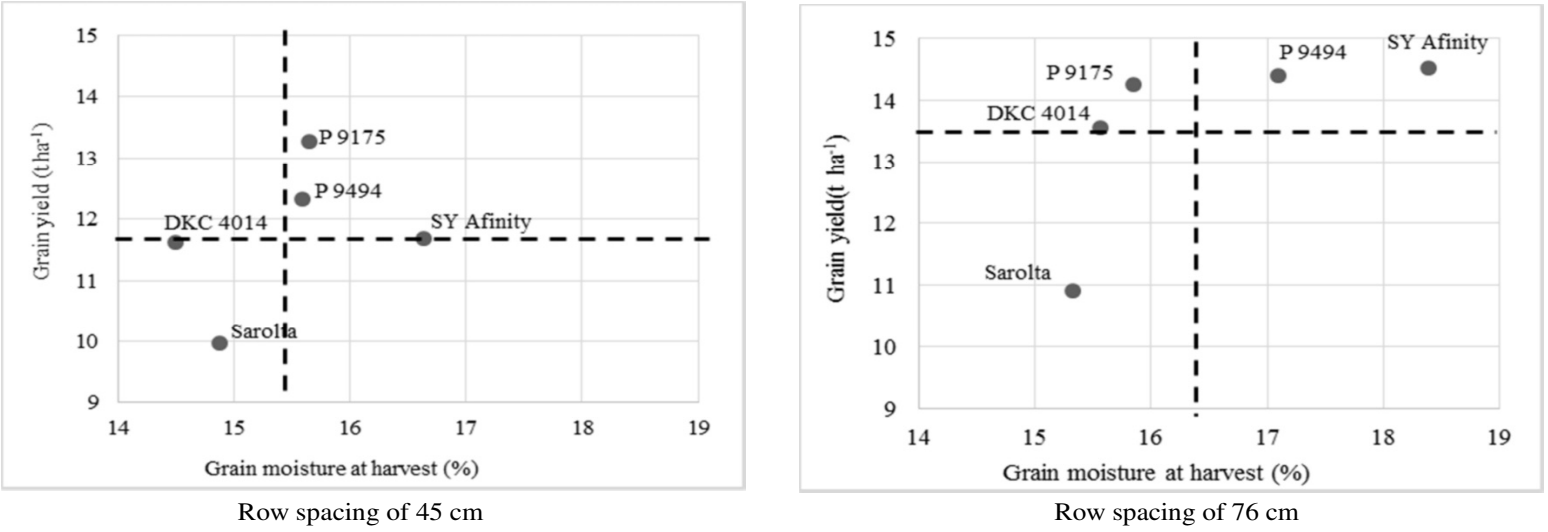

Figure 3: Relationship between yield amount (t ha-1) and its moisture content (\%) by row spacings of 45 and $76 \mathrm{~cm}$ in the crop year of 2015 (Debrecen - Látókép 2015)

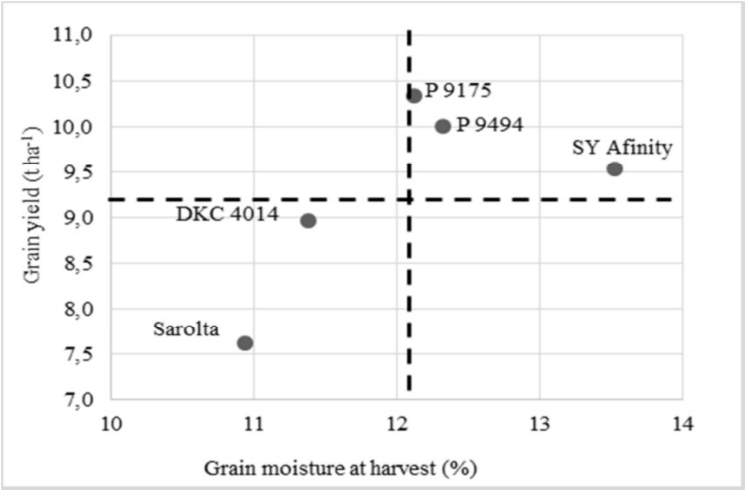

Row spacing of $45 \mathrm{~cm}$

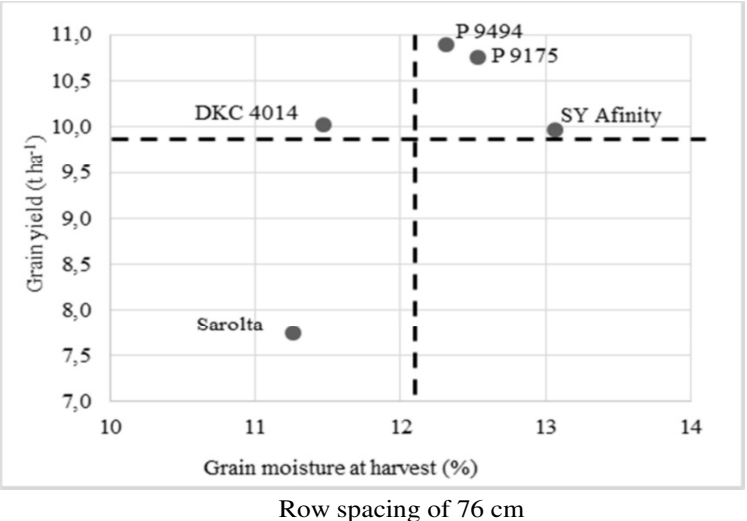




\section{CONCLUSIONS}

Due to the different weather conditions of the studied crop years, both yield amount and harvest moisture content showed different development. Crop year affected grain yield amount and its harvest moisture content. Significant difference $\left(14.9 \%, 1751 \mathrm{~kg} \mathrm{ha}^{-1} ; 6.3 \%\right.$, $583 \mathrm{~kg} \mathrm{ha}^{-1}$ ) could be found in case of yield between different row spacing applications in 2014 and 2015. The studied hybrids produced maximal yield amount in case of both row spacings by a plant density of 90000 plants $\mathrm{ha}^{-1}$ in the crop year of 2013. The amount of precipitation was adequate during the vegetation period of 2014; however, its distribution was unfavourable for maize population. The application of a row spacing of $76 \mathrm{~cm}$ resulted in somewhat lower yield amount than in the previous crop year in case of all plant densities, but yield decrease was not significant due to the effect of the crop year. By the application of a row spacing of $45 \mathrm{~cm}$ maximal yield amount was produced - in contrast to the previous crop year - in case of the application of a plant density of 50000 plants ha ${ }^{-1}$. The effect of insufficiently distributed low amount of precipitation and lasting heat days in 2015 could be revealed in yield amounts and harvest grain yield moisture content results that were lower than in the previous years.

Medium correlation $(0.411-0.519 * *)$ could be revealed between row spacing, yield, just as yield moisture content only in the crop year of 2014 among the studied crop years. Presenting yield and grain moisture content in a coordinate system hybrids can be categorized: the most favourable is if a given hybrid produces high yield amount with low grain moisture content.

\section{REFERENCES}

Farnham, E. D. (2001): Row spacing, plant density, and hybrid effects on corn grain yield and moisture. Agronomy Journal. 93. 5: 1049-1053.

Giesbrecht, J. (1969): Effect of population and row spacing on the performance of four corn (Zea mays L.) hybrids. Agronomy Journal. 61. 3: 439-441.

Johnson, G. A.-Hoverstad, T. R.-Greenwald, R. F. (1998): Integrated weed management using narrow corn row spacing, herbicides, and cultivation. Agronomy Journal. 90. 1: 40-46.

Lutz, A. J.-Camper, M. H.-Jones, D. G. (1971): Row spacing and population effects on corn yields. Agronomy Journal. 63. 1: 12-14.

Ma, B. L.-Dwyer, L. M.-Costa, C. (2003): Row spacing and fertilizer nitrogen effects on plant growth and grain yield of maize. Canadian Journal of Plant Science. 83. 2: 241-247.
Nagy M. (1983): A tenyészterület alak, sűríthetőség, levélfelületindex és a terméseredmények alakulása különböző kukorica hibrideknél. Agrártudományi Közlemények. 23: 259-274.

Porter, P. M.-Hicks, D. R.-Lueschen, W. E.-Ford, J. H.-Warnes, D. D.-Hoverstad, T. R. (1997): Corn response to row width and plant population in the Northern Corn Belt. Journal of Production Agriculture. 10. 2: 293-300.

Shapiro, C. A.-Wortmann, C. S. (2006): Corn response to nitrogen rate, row spacing, and plant density in Eastern Nebraska. Agronomy Journal. 98: 529-535

Sváb J. (1981): Biometriai módszerek a kutatásban. Mezőgazdasági Kiadó. Budapest. 171-179.

Widdicombe, D. W.-Thelen, D. K. (2002): Row width and plant density effects on grain production in the Northern Corn Belt. Agronomy Journal. 94. 5: 1020-1023. 